Article

\title{
Spineless Cactus plus Urea and Tifton-85 Hay: Maximizing the Digestible Organic Matter Intake, Ruminal Fermentation and Nitrogen Utilization of Wethers in Semi-Arid Regions
}

Robert E. Mora-Luna 1,2,*(D), Ana M. Herrera-Angulo ${ }^{1}$, Michelle C. B. Siqueira ${ }^{2}$, Maria Gabriela da Conceição ${ }^{2}$, Juana C. C. Chagas $^{3, *(D)}$, Carolina C. F. Monteiro ${ }^{2,4}\left(\mathbb{D}\right.$, Antonia S. C. Véras ${ }^{2}$, Francisco F. R. Carvalho ${ }^{2}$ and Marcelo A. Ferreira ${ }^{2}$

check for

updates

Citation: Mora-Luna, R.E.;

Herrera-Angulo, A.M.; Siqueira, M.C.B.; Conceição, M.G.d.; Chagas, J.C.C.; Monteiro, C.C.F.; Véras, A.S.C.; Carvalho, F.F.R.; Ferreira, M.A.

Spineless Cactus plus Urea and Tifton-85 Hay: Maximizing the Digestible Organic Matter Intake, Ruminal Fermentation and Nitrogen Utilization of Wethers in Semi-Arid Regions. Animals 2022, 12, 401. https://doi.org/10.3390/ ani12030401

Academic Editor:

Federico Infascelli

Received: 14 January 2022

Accepted: 2 February 2022

Published: 8 February 2022

Publisher's Note: MDPI stays neutral with regard to jurisdictional claims in published maps and institutional affiliations.

Copyright: (C) 2022 by the authors. Licensee MDPI, Basel, Switzerland. This article is an open access article distributed under the terms and conditions of the Creative Commons Attribution (CC BY) license (https:// creativecommons.org/licenses/by/ $4.0 /)$.
1 Deanship of Research, Coordination of Agricultural Research, National Experimental University of Táchira (UNET), San Cristobal 5001, Táchira, Venezuela; aherrera@unet.edu.ve

2 Department of Animal Science, Federal Rural University of Pernambuco (UFRPE), Recife 52171900, PE, Brazil; michelle.siqueira2@gmail.com (M.C.B.S.); gabizoo2283@hotmail.com (M.G.d.C.); monteirocarolinac@gmail.com (C.C.F.M.); antonia.veras@ufrpe.br (A.S.C.V.); francisco.rcarvalho@ufrpe.br (F.F.R.C.); marcelo.aferreira@ufrpe.br (M.A.F.)

3 Department of Agricultural Research for Northern Sweden, Swedish University of Agricultural Sciences (SLU), 90183 Umea, Sweden

4 Department of Animal Science, Alagoas State University (UNEAL), Santana do Ipanema 57500000, AL, Brazil

* Correspondence: robertmora78@yahoo.com (R.E.M.-L.); juana.chagas@slu.se (J.C.C.C.)

Simple Summary: In semi-arid regions, providing a roughage adapted to water deficient conditions, such as spineless cactus, associated with a source of physically effective fiber, could be a feed alternative for sheep. Five inclusion levels of spineless cactus plus urea and ammonium sulfate to replace Tifton-85 hay were tested in sheep diets with a roughage/concentrate ratio of 70:30. The dry matter and digestible organic matter intake, as well as ruminal fermentation, nitrogen balance, and microbial protein supply, were evaluated. The results suggested that spineless cactus inclusion affected quadratically the dry matter and digestible organic matter intake, as well as retained nitrogen and microbial protein supply. The spineless cactus plus urea and ammonium sulfate improved nitrogen utilization, reducing linearly urinary nitrogen excretion, serum urea, and ammonia plasma. On the other hand, spineless cactus inclusion increased the ruminal acetate and propionate concentrations, while ruminal $\mathrm{pH}$ and ruminal ammonia nitrogen were decreased. We recommend a roughage consisting of spineless cactus (plus urea and ammonium sulfate) and Tifton-85 hay in a 41:29 ratio, in order to maximize the digestible organic matter intake and $\mathrm{N}$-utilization. This could lead to an improvement in the productive performance of animals in semi-arid regions.

Abstract: The aim of this study was to evaluate the effect of replacing Tifton-85 hay (Cynodon spp. cv. Tifton 85) with 0, 150, 300, 450 and $600 \mathrm{~g} / \mathrm{kg}$ dry matter (DM) of spineless cactus (SC, Nopalea cochenilifera Salm-Dyck) plus urea and ammonium sulfate (UAS; 9:1) on DM, digestible organic matter (DOM) and indigestible neutral detergent fiber (iNDF) intakes, as well as ruminal fermentation, $\mathrm{N}$-balance, and microbial protein supply (MPS). Five rumen-fistulated and cannulated crossbred wethers, weighing $43.8 \pm 5.80 \mathrm{~kg}$, were randomized in a $5 \times 5$ Latin square design. Isonitrogenous diets (14\% crude protein) were supplied with a roughage/concentrate ratio of 70:30. The DOM intake, $\mathrm{N}$-retained, and MPS showed quadratic responses $(p<0.05)$, with maximum values estimated at the levels of SC+UAS of 414, 438 and $418 \mathrm{~g} / \mathrm{kg}$ DM, respectively. Rumen $\mathrm{pH}$ and ammonia nitrogen, iNDF intake, N-urinary excretion, and serum urea and plasma ammonia reduced linearly $(p<0.05)$ with increasing SC+UAS inclusion. Ruminal acetate and propionate concentrations increased linearly with increasing SC+UAS inclusion. In wethers fed diets with a roughage/concentrate ratio of 70:30, roughage constituted of a SC+UAS/hay (Tifton-85) ratio of 41:29 is recommended in order to maximize the DOM intake, N-retention, and MPS. 
Keywords: intake; nitrogen balance; roughage; ruminal fermentation; semi-arid

\section{Introduction}

Sheep production is a major economic activity in arid and semi-arid regions. Sheep can make use of low-quality biomass in times of scarcity and transform it into useful products, such as milk, meat and wool [1]. Considering the expansion of semi-arid regions [2,3], it is necessary to find a roughage source with great yield potential that is adapted to adverse edaphoclimatic effects, mostly water deficit [4]. Spineless cactus (SC) is a possible solution.

Spineless cactus is an excellent source of non-fiber carbohydrates (NFC; 52.3-66\%), but concentrations of neutral detergent fiber (NDF; $21.7-27.7 \%$ ) and crude protein (3.4-4.1\%) [5-7] are insufficient to sustain desired levels of animal performance. This roughage should thus be combined with another forage that provides physically effective fiber and a protein source [8].

Conserved forages, such as silage and hay, provided in semi-arid regions, are made and marketed in other regions without hydric limitations, an aspect that promotes increased feed expenses and forage prices greater than those of SC $(0.27$ vs. 0.13 US $\$ / \mathrm{kg}$ dry matter [DM]) [9]. However, offering these conserved forages as sources of physically effective fiber in combination with SC could provide a feed alternative to decrease costs and provide efficient resources for semi-arid regions. Tifton- 85 hay (Cynodon spp. cv. Tifton 85) can be used as a fiber source (NDF: $770 \mathrm{~g} / \mathrm{kg}$ DM) [10]. This roughage is considered a high-quality tropical forage, due to its rapid growth rate and high in vitro DM digestibility values (592 g/ kg DM) relative to other bermudagrass hybrids, such as Tifton-78, Tifton-44, and Coastal $(568,532$, and $523 \mathrm{~g} / \mathrm{kg} \mathrm{DM}$, respectively) [11].

It was hypothesized that there is a SC/Tifton- 85 hay ratio that maximizes nutrient intake and benefits in sheep diets. Thus, the aim was to evaluate the effect of the inclusion of SC (Nopalea cochenilifera Salm-Dyck) adjusted with urea and ammonium sulfate mix (UAS) in Tifton hay-based diets on DM, digestible organic matter (DOM), and indigestible neutral detergent fiber (iNDF) intakes, ruminal fermentation, nitrogen $(\mathrm{N})$ balance, and microbial protein supply (MPS).

\section{Materials and Methods}

The experiment was carried out in Animal Science Department at the Federal Rural University of Pernambuco, located in Recife, Pernambuco State, Brazil $\left(08^{\circ} 01^{\prime} 13.4^{\prime \prime} \mathrm{S}\right.$ $34^{\circ} 57^{\prime} 14.9^{\prime \prime} \mathrm{W}$ ), with climate classified according to Köppen-Geiger as tropical hot and humid (As') [12]. The altitude is $4 \mathrm{~m}$, with an annual precipitation averaging $1804 \mathrm{~mm}$ and an annual temperature averaging $27.5^{\circ} \mathrm{C}$, ranging from 24 to $31^{\circ} \mathrm{C}$.

The Tifton-85 hay was purchased from the local market in Recife, Pernambuco, Brazil, while SC was provided by the Caruaru Experimental Station of the Agronomic Institute of Pernambuco (IPA), Caruaru, Pernambuco, Brazil, situated $130 \mathrm{~km}$ away from Recife. The SC was harvested every 14 days, and was transported from Caruaru to Recife for storage.

The animals used in the experiment were registered and cared for in accordance with the guidelines and recommendations of the Committee of Ethics on Animal Studies at the Federal Rural University of Pernambuco (License $N^{\circ}$ 069/2016).

\subsection{Animals, Management, and Experimental Design}

Five rumen-fistulated and cannulated crossbred wethers (of no defined breed), averaging $43.8 \pm 5.80 \mathrm{~kg}$ body weight (BW) and $14 \pm 2.33$ months in age, were assigned randomly into five treatments on a $5 \times 5$ Latin square design. The animals were treated for internal parasites before the start of the experiment and were housed in individual pens $(0.93 \times 1.54 \mathrm{~m})$ fitted with feeders and a fresh water source. Water was offered ad libitum.

Diets were supplied ad libitum as a total mixed ration, twice per day at 8:00 and 16:00 $\mathrm{h}$. The amount of feed offered to the wethers was adjusted daily to allow refusals 
of approximately $5-10 \%$ of total DM provided. The experiment lasted 110 days with five experimental periods of 22 days, after 14 days of diet adaptation [13], and 8 days for sampling and data recording.

The chemical composition and nutritional value of the dietary ingredients are shown in Table 1. The experimental treatments are presented in Table 2 and consisted of Tifton- 85 hay as the exclusive source of roughage in the diet and replacement of $20,40,60$ and $80 \%$ of Tifton-85 hay by SC plus UAS mixture (9:1), which represented DM inclusions of 150, 300,450 and $600 \mathrm{~g} \mathrm{SC}+\mathrm{UAS} / \mathrm{kg} \mathrm{DM}$, respectively, in the diet. The UAS mixture was added to the diets in order to promote isonitrogenous experimental diets at $14 \%$ of crude protein concentration and to meet the requirements of sheep with an average daily gain of $250 \mathrm{~g} / \mathrm{d}$ [14]. The concentrates were composed of soybean meal, ground corn, common salt, and mineral mixture, with a roughage/concentrate ratio of 70:30 (Table 2).

Table 1. Chemical composition of ingredients (g/kg DM).

\begin{tabular}{|c|c|c|c|c|c|c|}
\hline Item & Tifton-85 Hay & Spineless Cactus & Soybean Meal & Ground Corn & Urea & Ammonium Sulfate \\
\hline $\mathrm{DM}^{\mathrm{a}}$ & 929 & 223 & 918 & 899 & 991 & 994 \\
\hline Ash & 103 & 92 & 74 & 16 & - & - \\
\hline $\mathrm{OM}$ & 897 & 908 & 926 & 984 & - & - \\
\hline $\mathrm{CP}$ & 118 & 33 & 518 & 100 & 2900 & 1295 \\
\hline EE & 14 & 15 & 16 & 44 & - & - \\
\hline aNDF(n) & 651 & 148 & 97 & 80 & - & - \\
\hline iNDF & 298 & 80 & 1.6 & 4.0 & - & - \\
\hline $\mathrm{ADF}$ & 366 & 98 & 85 & 30 & - & - \\
\hline Lignin & 62 & 10 & 4.3 & 10 & - & - \\
\hline NFC & 113 & 712 & 295 & 761 & - & - \\
\hline $\mathrm{TC}$ & 765 & 860 & 392 & 841 & - & - \\
\hline
\end{tabular}

${ }^{a} \mathrm{~g}$ DM/kg of fresh weight. DM: dry matter; OM: organic matter, CP: crude protein; EE: ether extract; aNDF(n): neutral detergent fiber corrected for ash and nitrogenous compounds; iNDF: indigestible neutral detergent fiber; ADF: acid detergent fiber; NFC: non-fibrous carbohydrates; TC: total carbohydrates.

Table 2. Proportion of ingredients and chemical composition of the experimental diets.

\begin{tabular}{|c|c|c|c|c|c|}
\hline \multirow{2}{*}{ Ingredients (g/kg DM) } & \multicolumn{5}{|c|}{ Inclusion of SC+UAS (g/kg DM) } \\
\hline & 0 & 150 & 300 & 450 & 600 \\
\hline Tifton-85 hay & 693 & 549 & 399 & 250 & 99 \\
\hline Spineless cactus & 0 & 147 & 293 & 437 & 583 \\
\hline Ground corn & 208 & 204 & 203 & 204 & 205 \\
\hline Soybean meal & 84 & 81 & 82 & 82 & 82 \\
\hline Urea + Ammonium sulfate ${ }^{a}$ & 0 & 4 & 8 & 12 & 16 \\
\hline Common salt & 5 & 5 & 5 & 5 & 5 \\
\hline Mineral mix $\mathrm{b}$ & 10 & 10 & 10 & 10 & 10 \\
\hline \multicolumn{6}{|l|}{ Chemical composition (g/kg DM) } \\
\hline $\mathrm{DM}^{\mathrm{c}}$ & 922 & 629 & 478 & 387 & 325 \\
\hline $\mathrm{OM}$ & 919 & 921 & 923 & 925 & 927 \\
\hline $\mathrm{CP}$ & 146 & 143 & 140 & 141 & 140 \\
\hline EE & 20 & 20 & 20 & 21 & 21 \\
\hline aNDF(n) & 476 & 404 & 327 & 252 & 175 \\
\hline iNDF & 208 & 176 & 143 & 111 & 77 \\
\hline $\mathrm{ADF}$ & 267 & 229 & 188 & 148 & 107 \\
\hline NFC & 277 & 361 & 449 & 534 & 621 \\
\hline TC & 753 & 757 & 762 & 765 & 769 \\
\hline aNDF(n) from Tifton-85 hay & 452 & 358 & 260 & 163 & 65 \\
\hline
\end{tabular}

a 9 parts of urea and 1 part of ammonium sulphate. ${ }^{\text {b }}$ Assurance levels provided by the manufacturer: $(\mathrm{g} / \mathrm{kg})$ $120 \mathrm{Ca}, 87 \mathrm{P}, 147 \mathrm{Na}, 18 \mathrm{~S},(\mathrm{mg} / \mathrm{kg}) 590 \mathrm{Cu}, 40 \mathrm{Co}, 20 \mathrm{Cr}, 1800 \mathrm{Fe}, 80 \mathrm{I}, 1300 \mathrm{Mn}, 15 \mathrm{Se}, 3800 \mathrm{Zn}, 10 \mathrm{Mo}$ and $870 \mathrm{~F}$ (maximum). ${ }^{\mathrm{c}} \mathrm{g} \mathrm{DM} / \mathrm{kg}$ of fresh weight. DM: dry matter; OM: organic matter; CP: crude protein; EE: ether extract; aNDF(n): neutral detergent fiber corrected for ash and nitrogenous compounds; iNDF: indigestible neutral detergent fiber; ADF: acid detergent fiber; NFC: non-fibrous carbohydrates; TC: total carbohydrates. 


\subsection{Data and Sample Collection}

The roughage and concentrate were offered and refusals were weighed daily (Ramuza Scale, Model Ramuzatron 15, Santana de Parnaíba, São Paulo, Brazil) from the 15th to the 22nd day of the experimental period, for estimation of the nutrient intake. Samples of feeds and refusals were pre-dried in a forced-air oven (Tecnal, Model TE 394-2, Piracicaba, São Paulo, Brazil) at $55^{\circ} \mathrm{C}$ to constant weight, and one sample was prepared per animal in each period for subsequent chemical analysis.

To estimate the DOM intake, the total fecal collection was performed from the 17 th to the 19th day of each experimental period, using collection bags fixed on the animals. Feces were removed from the collection bags every $6 \mathrm{~h}$. Samples of each collection day were immediately pre-dried in a forced-air oven at $55{ }^{\circ} \mathrm{C}$ for $72 \mathrm{~h}$. A composite sample was obtained for each animal in each period for chemical analysis.

On the 16th day of each period, samples of ruminal contents were taken at $0 \mathrm{~h}$ (before the morning feeding was offered) and at 2, 4, 6, and $8 \mathrm{~h}$ after the feed was offered. Samples were collected from the anterior dorsal, anterior ventral, medium ventral, and posterior dorsal ruminal regions. Ruminal contents were filtered through four layers of cheesecloth for immediate $\mathrm{pH}$ determination by using a pH meter (Kasvi, Model K39-0014P, São José do Pinhais, Paraná, Brazil). From the extracted ruminal fluid (at each pH sampling time), 30-mL aliquots were deposited in plastic vials with $1.5 \mathrm{~mL} 6 \mathrm{~N} \mathrm{HCl}$. The samples were stored at $-20{ }^{\circ} \mathrm{C}$ until analysis of rumen ammonia nitrogen (RAN) and volatile fatty acids (VFAs).

To estimate N-balance and purine derivative (PD) excretion, total urine collection was performed during the three days of fecal collection. Funnels and hoses were coupled to abdominal area and penis of the animals, and urine was conducted into a container containing $100 \mathrm{~mL}$ of $10 \%$ sulfuric acid. The $\mathrm{pH}$ was measured every $6 \mathrm{~h}$ to keep it below 3.0 [15] to prevent both ammonia N-loss [16] and bacterial destruction of PDs [17]. At the end of each collection day, weight and total urine volume were determined, which was diluted to $4 \mathrm{~L}$ [16] with distilled water and filtered through four layers of cheesecloth. Aliquots of $50 \mathrm{~mL}$ were frozen at $-20^{\circ} \mathrm{C}$ for chemical analysis.

On the 19th day of each experimental period, blood samples were extracted from the animals $4 \mathrm{~h}$ after morning feeding by jugular puncture with $21 \mathrm{G} \times 1$ " needles (Vacuette, Greiner Bio-One, Kremsmünster, Austria), using Vacuette tubes (Greiner Bio-One, Americana, São Paulo, Brazil) with and without anticoagulant (EDTA). Blood samples were centrifuged (Centribio, Model 80-2B $15 \mathrm{~mL}$, Mombai, India) at $1016 \times g$ for $15 \mathrm{~min}$, and the plasma and serum obtained stored at $-20^{\circ} \mathrm{C}$.

\subsection{Chemical Analyses}

Composite samples of feed, refusals, and feces were ground in a Willey mill (Marconi, Model MA 340, Piracicaba, Brazil) in 1- and 2-mm sieves for chemical analysis. According to the AOAC [18], the samples were analyzed for DM by gravimetric estimation at $105^{\circ} \mathrm{C}$ (code 930.04), for $\mathrm{N}$ by the Kjeldahl method (code 984.13), and for ash by ignition at $600{ }^{\circ} \mathrm{C}$ (code 942.05). All these chemical analyses were performed in samples processed in 1-mm sieve. Urine $\mathrm{N}$ was determined by the Kjeldahl method.

To determine iNDF concentration and iNDF intake, feed and refusal samples (processed in 2-mm sieve) were incubated in a bovine rumen for $288 \mathrm{~h}$ [19] for subsequent determination of NDF concentration. The NDF (ingredients, refusals, feces, rumen-incubated material) determinations were made with heat-stable amylase (Termamyl 2X, Novozymes, Copenhagen, Denmark) without sodium sulfite [20], corrected for nitrogen compounds [21], and expressed as ash-free organic matter (OM) (aNDF(n) [20]. Acid detergent fiber and lignin for all ingredients were determined according to Van Soest [22], with the exception that lignin concentration of SC was determined by potassium permanganate oxidation [23].

For rumen VFA and RAN determination, upon thawing, a 7-mL aliquot of ruminal fluid samples were centrifuged (CentriBio, Modelo 80-2B-15 mL, Mumbai, India) at $1016 \times g$ for $10 \mathrm{~min}$ and the supernatant used for VFA determination (acetate, propionate, 
and butyrate) by gas chromatography [24]. CG-Master (Brazil) equipment with a flame ionization detector and Carbowax column (DB-Wax; $60 \mathrm{~m}, 0.25 \mathrm{~mm} \times 1 \mu \mathrm{m}$ ) was used. Vaporizer, detector, and oven temperatures were 200,200 , and $120{ }^{\circ} \mathrm{C}$, respectively. A 2-mL aliquot of supernatant was recentrifuged at $20,817 \times g$ and $4{ }^{\circ} \mathrm{C}$ for $30 \mathrm{~min}$ (Eppendorf, Model AG2231, Hamburg, Germany) and the supernatant used for RAN determination by colorimetry [25]; the absorbance was measured on an Agilent spectrophotometer (Model 8453, Santa Clara, CA, USA).

To determine glucose (in serum), uric acid (in urine) and urea (in serum and urine), Labtest kits (Labtest Diagnostica SA, Lagoa Santa, Minas Gerais, Brazil) were used in Labmax 240 equipment (Labtest, Prestige Model 24i, Tokyo, Japan). For the determination of urine ammonia, the colorimetric procedure of Chaney and Marbach [25] was used, and an adaptation of this method was used for plasma ammonia determination [26]. Urine allantoin concentration was determined by colorimetry as described by Chen and Gomes [17], and the absorbance was measured on the spectrophotometer previously described.

\subsection{Calculations}

Chemical compositions of diets were calculated from the proportion of ingredients and their respective values. The NFC was calculated according to Detmann and Valadares Filho [27]. The OM was calculated as $1000 \mathrm{~g} / \mathrm{kg} \mathrm{DM}-\mathrm{g}$ ash/kg DM. The DM, iNDF, and $\mathrm{N}$ intakes were calculated by subtracting their contents in the refusals from the daily amounts offered. Nitrogen balance estimate was obtained by subtracting urinary and fecal $\mathrm{N}$-excretion from $\mathrm{N}$-consumption, the latter recorded during the three days of collection of feces and urine.

The PDs excreted were calculated as the sum of daily urinary excretion of allantoin and uric acid, without considering xanthine and hypoxanthine excretion, since allantoin + uric acid is highly correlated with rumen nucleic acid concentration [28]. The PDs absorbed were calculated according to the mathematical model described by Chen et al. [15]. The microbial N-supply (MNS) was estimated according to Chen et al. [16] and the MPS was calculated as MNS $\times$ 6.25. Digestible OM intake was calculated as OM intake $\times \mathrm{OM}$ digestibility, and the digestible OM apparently digested in the rumen (DOMR) was calculated assuming 65\% of DOM intake [29].

\subsection{Statistical Analysis}

Data were analyzed by ANOVA using the MIXED procedure of SAS (Version 9.4; SAS Inst., Inc., Cary, NC, USA) according to a $5 \times 5$ Latin square design. The statistical model used was

$$
Y_{i j k}=\mu+D_{i}+P_{j}+A_{k}+E_{i j k}
$$

where $Y_{i j k}$ is a dependent variable, $\mu$ is the mean for all observations, $D_{i}$ is the fixed effect of diet $i, P_{j}$ is the random effect of period $j, A_{k}$ is the random effect of animal $k$, and $E_{i j k} \sim N\left(0, \sigma^{2}{ }_{e}\right)$ represents the residual error.

Rumen $\mathrm{pH}, \mathrm{RAN}$, and VFA were analyzed as repeated measures data [30]. The statistical model used was

$$
Y_{i j k}=\mu+D_{i}+P_{j}+A_{k}+T_{l}+(D \times T)_{i l}+E_{i j k}
$$

where $Y_{i j k}$ is a dependent variable, $\mu$ is the mean for all observations, $D_{i}$ is the fixed effect of diet $i, P_{j}$ is the random effect of period $j, A_{k}$ is the random effect of animal $k, T_{l}$ is the fixed effect of collection time $l,(D \times T)_{i l}$ is the fixed interaction effect of diet $i$ with the collection time $l$, and $E_{i j k l} \sim N\left(0, \sigma^{2}{ }_{e}\right)$ represents the residual error.

Orthogonal polynomial contrasts were used to determine linear and quadratic effects. Differences were declared statistically significant at $p<0.05$. When there were significant interactions, the PLM procedure of SAS and the Tukey-Kramer test were used.

For the variables with a quadratic response, curve fitting and equations were obtained by regression analysis. Maximum or minimum SC+UAS inclusion levels were obtained 
setting the first derivative of the equation $\left(y=a x^{2}+b x+c\right)$ equal to zero. Thus, the respective maximum or minimum response values for the parameters studied were estimated by replacing " $x$ " in the equation with the SC+UAS inclusion level previously estimated.

\section{Results}

\subsection{DM, DOM, and iNDF Intake}

The intake of DM (g/d), DOM, and DM, expressed as $\mathrm{g} / \mathrm{kg} \mathrm{BW}$, showed a quadratic response $(p<0.05$; Table 3$)$, with maximum values of $1281 \mathrm{~g} / \mathrm{d}, 910 \mathrm{~g} / \mathrm{d}$, and $27 \mathrm{~g} / \mathrm{kg} \mathrm{BW}$, respectively, for the same inclusion levels of 356,414 , and $343 \mathrm{~g} \mathrm{SC+UAS} / \mathrm{kg} D \mathrm{DM}$. On the other hand, iNDF intake decreased linearly with increasing SC+UAS inclusion $(p<0.001)$.

Table 3. Effect of SC+UAS inclusion on dry matter, digestible organic matter, and indigestible neutral detergent fiber intakes.

\begin{tabular}{|c|c|c|c|c|c|c|c|c|}
\hline \multirow{2}{*}{ Item } & \multicolumn{5}{|c|}{ Inclusion of SC+UAS (g/kg DM) } & \multirow{2}{*}{ SEM } & \multicolumn{2}{|c|}{$p$-Value } \\
\hline & 0 & 150 & 300 & 450 & 600 & & $\mathbf{L}$ & $\mathbf{Q}$ \\
\hline DMI & & & & & & & & \\
\hline $\mathrm{g} / \mathrm{d}$ & 1110 & 1179 & 1379 & 1185 & 1236 & 78.6 & 0.066 & $0.014^{\mathrm{a}}$ \\
\hline $\mathrm{g} / \mathrm{kg} \mathrm{BW}$ & 24 & 26 & 30 & 26 & 27 & 2.25 & 0.086 & $0.027^{\mathrm{b}}$ \\
\hline $\begin{array}{l}\text { DOMI }(\mathrm{g} / \mathrm{d}) \\
\text { iNDFI }\end{array}$ & 692 & 782 & 984 & 839 & 905 & 59.0 & 0.001 & $0.012^{\mathrm{c}}$ \\
\hline $\mathrm{g} / \mathrm{d}$ & 217 & 189 & 171 & 106 & 91 & 15.5 & 0.000 & 0.577 \\
\hline $\mathrm{g} / \mathrm{kg}$ DMI & 194 & 160 & 124 & 89 & 73 & 5.29 & 0.000 & 0.175 \\
\hline
\end{tabular}

DMI: dry matter intake; BW: body weight; DOMI: digestible organic matter intake; iNDFI: indigestible neutral detergent fiber intake; SEM: standard error of the mean; $\mathrm{L}$ : linear; $\mathrm{Q}$ : quadratic. ${ }^{\mathrm{a}} \mathrm{DMI}(\mathrm{g} / \mathrm{d})=-0.0014(\mathrm{SC}+\mathrm{UAS})^{2}$ $+0.9952(\mathrm{SC}+\mathrm{UAS})+1104.5$. $\mathrm{b}$ DMI $(\mathrm{g} / \mathrm{kg} \mathrm{BW})=-0.00003(\mathrm{SC}+\mathrm{UAS})^{2}+0.0206(\mathrm{SC}+\mathrm{UAS})+23.869$. ${ }^{c} \mathrm{DOMI}=-0.0013(\mathrm{SC}+\mathrm{UAS})^{2}+1.0759(\mathrm{SC}+\mathrm{UAS})+687.21$.

\subsection{Ruminal Fermentation}

Rumen $\mathrm{pH}$ and RAN (Table 4) showed linear reductions when the diet included increasing levels of SC+UAS $(p<0.001)$. There was a quadratic response for both $\mathrm{pH}$ and RAN as a function of collection time $(p<0.001)$. A minimum $\mathrm{pH}$ value $(6.18)$ was measured $5.17 \mathrm{~h}$ after the morning feeding, whereas a maximum RAN value $(188.8 \mathrm{mg} / \mathrm{L})$ was detected $1.84 \mathrm{~h}$ after feeding.

Table 4. Effects of SC+UAS inclusion on ruminal fermentation of wethers.

\begin{tabular}{|c|c|c|c|c|c|c|c|c|c|c|c|c|c|c|c|c|c|}
\hline \multirow{3}{*}{ Item } & \multicolumn{5}{|c|}{ Inclusion of SC+UAS (g/kg DM) } & \multirow{3}{*}{ SEM } & \multicolumn{5}{|c|}{ Collection Times (Hours) } & \multirow{3}{*}{ SEM } & \multicolumn{5}{|c|}{$p$-Value } \\
\hline & \multirow[b]{2}{*}{0} & \multirow[b]{2}{*}{150} & \multirow[b]{2}{*}{300} & \multirow[b]{2}{*}{450} & \multirow[b]{2}{*}{600} & & \multirow[b]{2}{*}{0} & \multirow[b]{2}{*}{2} & \multirow[b]{2}{*}{4} & \multirow[b]{2}{*}{6} & \multirow[b]{2}{*}{8} & & \multicolumn{2}{|c|}{ SC+UAS } & \multicolumn{2}{|c|}{ Collection Time } & \multirow{2}{*}{ Interaction } \\
\hline & & & & & & & & & & & & & $\mathbf{L}$ & $\mathbf{Q}$ & L & Q & \\
\hline $\mathrm{pH}$ & 6.54 & 6.47 & 6.27 & 6.22 & 6.16 & 0.07 & 6.62 & 6.33 & 6.20 & 6.21 & 6.30 & 0.05 & $<0.001$ & 0.495 & $<0.001$ & $<0.001^{\mathrm{a}}$ & 0.354 \\
\hline RAN $^{1}$ & 172 & 148 & 149 & 138 & 137 & 8.10 & 140 & 281 & 129 & 102 & 92 & 6.44 & 0.005 & 0.258 & $<0.001$ & $<0.001^{b}$ & $<0.001$ \\
\hline Acetate $^{2}$ & 53 & 54 & 59 & 59 & 63 & 4.46 & 51 & 59 & 61 & 61 & 57 & 3.41 & 0.048 & 0.978 & 0.019 & $<0.001^{\mathrm{c}}$ & 0.777 \\
\hline Propionate $^{2}$ & 13 & 13 & 19 & 23 & 28 & 2.50 & 15 & 20 & 21 & 21 & 20 & 1.54 & $<0.001$ & 0.386 & $<0.001$ & $<0.001^{\mathrm{d}}$ & 0.033 \\
\hline Butyrate $^{2}$ & 9 & 9 & 10 & 10 & 12 & 0.97 & 10 & 10 & 10 & 11 & 10 & 0.53 & 0.074 & 0.798 & 0.108 & 0.214 & 0.655 \\
\hline $\mathrm{A}: \mathrm{P}^{3}$ & 4.2 & 4.1 & 3.2 & 2.8 & 2.3 & 0.26 & 3.7 & 3.4 & 3.2 & 3.2 & 3.3 & 0.14 & $<0.001$ & 0.817 & $<0.001$ & $<0.001^{\mathrm{e}}$ & 0.146 \\
\hline Total VFA ${ }^{2}$ & 75 & 77 & 88 & 93 & 103 & 6.78 & 75 & 88 & 93 & 92 & 87 & 5.00 & 0.001 & 0.681 & 0.001 & $<0.001^{\mathrm{f}}$ & 0.494 \\
\hline
\end{tabular}

RAN: rumen ammonia nitrogen. ${ }^{1} \mathrm{mg} / \mathrm{L} .{ }^{2} \mathrm{mmol} / \mathrm{L} .{ }^{3}$ Acetate:Propionate ratio. SEM: standard error of the mean L: linear; Q: quadratic. Linear and quadratic effects are significant at $p<0.05$. H: hour. ${ }^{a} \mathrm{pH}=0.0161 \mathrm{H}^{2}-0.1666 \mathrm{H}$ $+6.6126 .{ }^{\mathrm{b}} \mathrm{RAN}=-3.1732 \mathrm{H}^{2}+11.651 \mathrm{H}+178.15 .{ }^{c}$ Acetate $=-0.4732 \mathrm{H}^{2}+4.5107 \mathrm{H}+50.914 .{ }^{\mathrm{d}}$ Propionate $=$ $-0.2393 \mathrm{H}^{2}+2.4743 \mathrm{H}+15.166 .{ }^{\mathrm{e}} \mathrm{A}: \mathrm{P}: 0.0155 \mathrm{H}^{2}-0.1768 \mathrm{H}+3.6763 .{ }^{\mathrm{f}} \mathrm{VFA}=-0.7429 \mathrm{H}^{2}+7.3329 \mathrm{H}+75.497$.

No interaction was seen between inclusion levels of SC and collection time regarding $\mathrm{pH}(p=0.354)$, whereas RAN did exhibit an interaction $(p<0.001$; Table 4 and Figure 1$)$. At time 0 (before feeding), the lowest concentration was observed at $600 \mathrm{~g} \mathrm{SC}+\mathrm{UAS} / \mathrm{kg}$ DM $(68 \mathrm{mg} / \mathrm{L})$. All treatments displayed greater RAN concentrations at $2 \mathrm{~h}(p<0.001)$, with the highest concentration detected in the $600 \mathrm{~g} \mathrm{SC}+\mathrm{UAS} / \mathrm{kg}$ DM treatment $(334.2 \mathrm{mg} / \mathrm{L}$; $p<0.001)$. Four hours after feeding, the highest RAN concentration was observed for $0 \mathrm{~g}$ $\mathrm{SC}+\mathrm{UAS} / \mathrm{kg} \mathrm{DM}(167.1 \mathrm{mg} / \mathrm{L})$, and the lowest for $300 \mathrm{~g} \mathrm{SC}+\mathrm{UAS} / \mathrm{kg} \mathrm{DM}(p=0.022)$. The 
$0 \mathrm{~g} \mathrm{SC}+\mathrm{UAS} / \mathrm{kg}$ DM treatment led to similar RAN concentrations at $0,4,6$ and $8 \mathrm{~h}$, and the same behavior was observed at the level of $150 \mathrm{~g} \mathrm{SC}+\mathrm{UAS} / \mathrm{kg} \mathrm{DM}$.

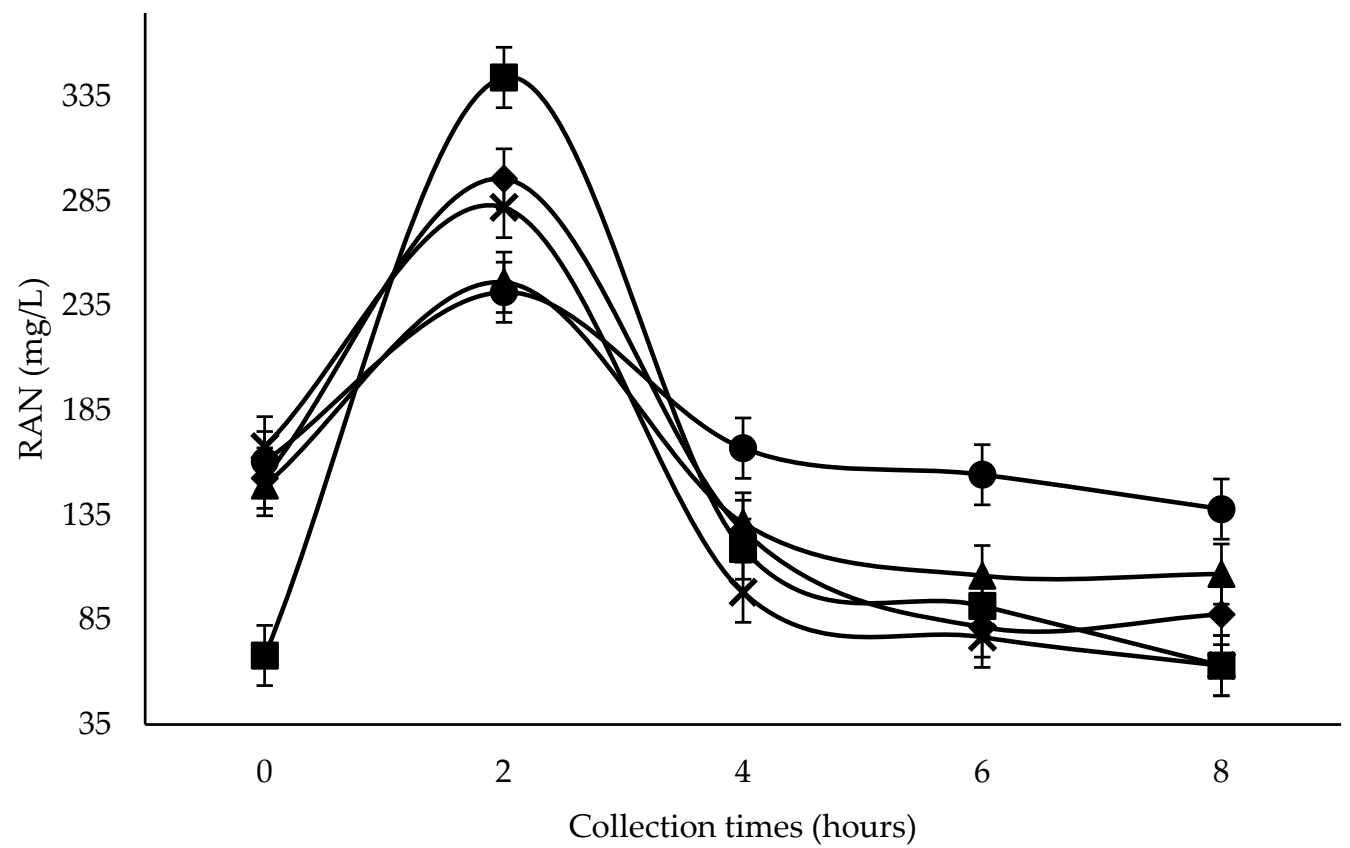

Figure 1. Effect of Treatment $\times$ Collection time interaction $(p<0.001)$ on rumen ammonia nitrogen $(\mathrm{RAN})$ concentration in wethers feeding with $0(\bullet), 150(\boldsymbol{\Delta}), 300(\bullet), 450(\times)$ and $600(\boldsymbol{\square}) \mathrm{g}$ SC+UAS/kg DM.

Acetate and propionate concentrations (Table 4) increased linearly with increasing SC+UAS inclusion $(p<0.05)$. Collection time showed a quadratic response $(p<0.001)$. Maximum concentrations were estimated at 61.7 and $21.6 \mathrm{mmol} / \mathrm{L}$, at 4.77 and $5.17 \mathrm{~h}$ after feeding, respectively, for the same acid order (Table 4$)$. There was an interaction between inclusion level and collection time for propionate concentration ( $p=0.033$; Table 4 and Figure 2). Analyzing each inclusion level during $8 \mathrm{~h}$ of collection, the levels of 0 and $150 \mathrm{~g} \mathrm{SC}+\mathrm{UAS} / \mathrm{kg}$ DM did not differ in acid concentration for the five collection times ( $p=0.896$ and 0.471 , respectively). Other inclusion levels led to changes in propionate concentration $(p<0.01)$, with lower values at the first collection $(0 \mathrm{~h})$. The level of $300 \mathrm{~g}$ $\mathrm{SC}+\mathrm{UAS} / \mathrm{kg}$ DM increased propionate concentrations at each collection time, while for 450 and $600 \mathrm{~g} \mathrm{SC}+\mathrm{UAS} / \mathrm{kg} \mathrm{DM}$, higher concentrations were detected at 4 and $6 \mathrm{~h}$, respectively. Analyzing the response of the inclusion levels of SC at each collection time, the greatest overall propionate concentrations were observed at $600 \mathrm{~g}$ SC+UAS/kg DM, except at $2 \mathrm{~h}$ when similar concentrations were observed for 450 and $600 \mathrm{~g} \mathrm{SC}+\mathrm{UAS} / \mathrm{kg}$ DM. Lower propionate concentrations were observed at the two lower SC inclusion levels (0 and $150 \mathrm{~g} \mathrm{SC}+\mathrm{UAS} / \mathrm{kg} \mathrm{DM})$.

Butyrate concentration (Table 4) was not influenced by inclusion of SC or collection time, nor was there an interaction between inclusion level and collection time $(p>0.05)$. Acetate/propionate ratio (Table 4 ) decreased linearly with increasing SC+UAS inclusion $(p<0.001)$. A quadratic decrease $(p<0.001)$ was observed in the acetate/propionate ratio with collection time, with a minimum value of 3.17 detected $5.70 \mathrm{~h}$ after feeding. Total VFA concentration increased linearly with increasing SC+UAS inclusion $(p=0.001$; Table 4$)$. Regarding collection time, total VFA concentration showed a quadratic response $(p<0.001)$, with a maximum concentration of $93.6 \mathrm{mmol} / \mathrm{L}$ detected at $4.94 \mathrm{~h}$ after the first feeding.

Nitrogen balance is presented in Table 5 . Urinary N-excretion $\left(\mathrm{g} / \mathrm{d} ; \mathrm{g} / \mathrm{kg} \mathrm{BW}^{0.75}\right)$ and the $\mathrm{N}$-intake to DOM-intake ratio decreased linearly $(p<0.05)$ with increasing SC+UAS inclusion. A quadratic response $(p=0.019)$ was observed in urinary N-excretion $(\mathrm{g} / \mathrm{kg}$ $\mathrm{N}$-intake), with a minimum excretion of $332.2 \mathrm{~g} / \mathrm{kg} \mathrm{N}$ detected at $393.1 \mathrm{~g} \mathrm{SC}+\mathrm{UAS} / \mathrm{kg}$ DM. Nitrogen retained showed a quadratic response $(p<0.05)$ with SC+UAS inclusion. 
Maximum N-retention was estimated at $14.1 \mathrm{~g} / \mathrm{d}, 0.72 \mathrm{~g} / \mathrm{kg} \mathrm{BW}$. 75 , and $593.1 \mathrm{~g} \mathrm{~N} / \mathrm{kg}$ $\mathrm{N}$ absorbed, measured at levels 438.3, $350 \mathrm{~g}$, and 440.1 SC+UAS/kg DM, respectively. Nitrogen retained decreased linearly $(p=0.008)$ when considering the $\mathrm{N}$ ingested, whereas $\mathrm{N}$-retention considering the $\mathrm{N}$ absorbed showed a quadratic response $(p=0.044)$. Maximum retention was estimated at $593.1 \mathrm{~g} \mathrm{~N} / \mathrm{kg} \mathrm{N}$ absorbed at the level of $440.1 \mathrm{~g} \mathrm{SC}+\mathrm{UAS} / \mathrm{kg} \mathrm{DM}$.

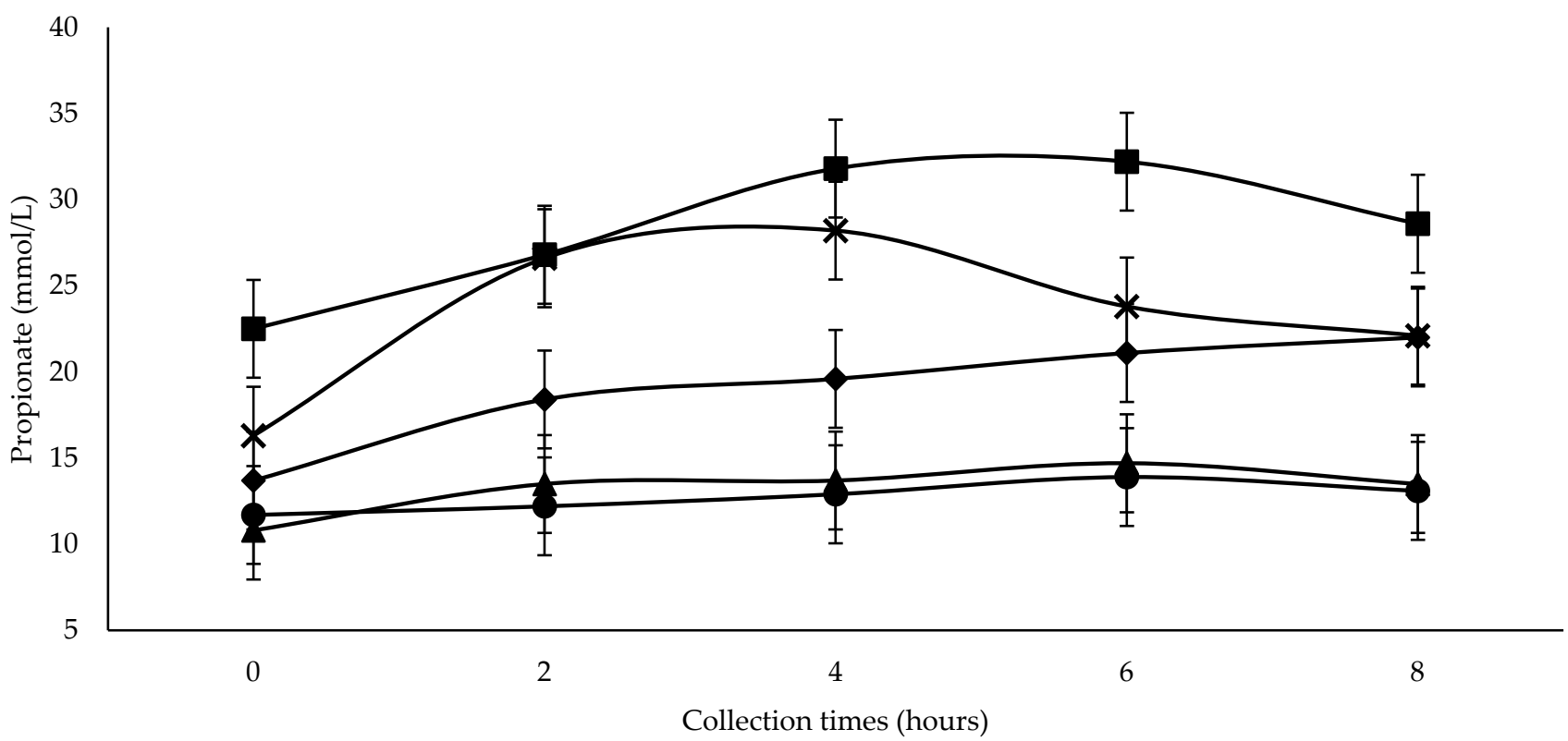

Figure 2. Effect of Treatment $\times$ Collection time interaction $(p=0.033)$ on propionate concentration in wethers feeding with $0(\bullet), 150(\boldsymbol{\Delta}), 300(\diamond), 450(\times)$ and $600(\boldsymbol{\square}) \mathrm{g} \mathrm{SC}+\mathrm{UAS} / \mathrm{kg}$ DM.

\subsection{Nitrogen Balance, Nitrogen Compounds, and Blood Glucose}

Nitrogen ingested $\left(\mathrm{g} / \mathrm{d}\right.$ and $\left.\mathrm{g} / \mathrm{kg} \mathrm{BW}^{0.75}\right)$ and fecal $\mathrm{N}(\mathrm{g} / \mathrm{d})$ showed a quadratic increase $\left(p<0.05\right.$; Table 5), with maximum values of $30 \mathrm{~g} / \mathrm{d}, 1.66 \mathrm{~g} / \mathrm{kg} \mathrm{BW} \mathrm{BW}^{0.75}$ and $6.45 \mathrm{~g} / \mathrm{d}$, respectively, for the same level order of 363.3, 300, and $244.4 \mathrm{~g} \mathrm{SC}+\mathrm{US} / \mathrm{kg} \mathrm{DM}$. Nitrogen excretion via feces ( $\mathrm{g} / \mathrm{kg} \mathrm{BW}{ }^{0.75}$ and $\mathrm{g} / \mathrm{kg} \mathrm{N}$ consumed) and $\mathrm{N}$ absorbed $(\mathrm{g} / \mathrm{d}$ and $\mathrm{g} / \mathrm{kg}$ $\left.\mathrm{BW}^{0.75}\right)$ were not affected by inclusion $(p>0.05)$.

Concentrations of serum urea, plasma ammonia, urine ammonia and N-excretion decreased as urine ammonia $(\mathrm{g} / \mathrm{d})$ decreased, while serum glucose increased linearly $(p<0.05)$ with increasing SC+UAS inclusion (Table 5). Urinary urea concentration, daily excretion of $\mathrm{N}$-urea and $\mathrm{N}$ excreted as ammonia expressed as a percentage of total $\mathrm{N}$ excreted in the urine were not influenced by inclusion $(p>0.05)$. However, N-excretion as urea, expressed as a percentage of $\mathrm{N}$ excreted via urine, displayed a quadratic response $(p=0.038)$ with a maximum value $76.8 \%$ at $538 \mathrm{~g} \mathrm{DM} / \mathrm{kg} \mathrm{SC}+\mathrm{UAS}$.

\subsection{Urinary Volume, PD, and MPS}

Urinary volume and urine allantoin concentration were similar $(p>0.05)$, while daily uric acid concentration and excretion increased linearly with increasing SC+UAS inclusion $(p<0.05$; Table 6). Allantoin daily excretion, excreted and absorbed PD, MNS and MPS showed quadratic responses $(p<0.05)$ with maximum values estimated at $8.83 \mathrm{mmol} / \mathrm{d}$, $8.51 \mathrm{mmol} / \mathrm{d}, 10.9 \mathrm{mmol} / \mathrm{d}, 7.08 \mathrm{~g} / \mathrm{d} \mathrm{N}$, and $48.8 \mathrm{~g} / \mathrm{d}$ MPS, respectively, for the same order of SC+UAS inclusion levels of 585, 345, 462.5, 335, and $418 \mathrm{~g} / \mathrm{kg}$ DM. The efficiency of MPS per $\mathrm{kg}$ of DOM intake or $\mathrm{kg}$ of DOMR intake was not influenced by inclusion of SC+UAS $(p>0.05)$. 
Table 5. Apparent nitrogen balance, serum and urine urea, plasma and urine ammonia, and serum glucose.

\begin{tabular}{|c|c|c|c|c|c|c|c|c|}
\hline \multirow{2}{*}{ Item } & \multicolumn{5}{|c|}{ Inclusion of SC+UAS (g/kg DM) } & \multirow{2}{*}{ SEM } & \multicolumn{2}{|c|}{$p$-Value } \\
\hline & $\mathbf{0}$ & 150 & 300 & 450 & 600 & & $\mathbf{L}$ & $\mathbf{Q}$ \\
\hline $\mathrm{N}$ intake & & & & & & & & \\
\hline $\mathrm{g} / \mathrm{d}$ & 26.0 & 28.1 & 31.6 & 26.9 & 27.8 & 1.99 & 0.485 & $0.024^{\mathrm{a}}$ \\
\hline $\mathrm{g} / \mathrm{kg} \mathrm{BW}^{0.75}$ & 1.46 & 1.59 & 1.76 & 1.51 & 1.56 & 0.12 & 0.503 & $0.022^{b}$ \\
\hline $\begin{array}{l}\mathrm{N} \text { fecal } \\
\mathrm{g} / \mathrm{d}\end{array}$ & 5.86 & 6.42 & 6.61 & 5.78 & 5.42 & 0.45 & 0.153 & $0.033^{c}$ \\
\hline $\mathrm{g} / \mathrm{kg} \mathrm{BW}^{0.75}$ & 0.33 & 0.36 & 0.37 & 0.33 & 0.31 & 0.03 & 0.191 & 0.053 \\
\hline $\mathrm{g} / \mathrm{kg} \mathrm{N}$ intake & 233 & 231 & 209 & 216 & 194 & 13.5 & 0.055 & 0.832 \\
\hline Nurinary & & & & & & & & \\
\hline $\mathrm{g} / \mathrm{d}$ & 11.8 & 10.7 & 10.1 & 9.46 & 9.71 & 0.65 & 0.011 & 0.214 \\
\hline $\mathrm{g} / \mathrm{kg} \mathrm{BW}^{0.75}$ & 0.66 & 0.60 & 0.56 & 0.53 & 0.54 & 0.04 & 0.011 & 0.238 \\
\hline $\begin{array}{l}\mathrm{g} / \mathrm{kg} \mathrm{N} \text { intake } \\
\text { N absorbed }\end{array}$ & 475 & 383 & 318 & 356 & 349 & 29.1 & 0.006 & $0.019^{d}$ \\
\hline $\mathrm{g} / \mathrm{d}$ & 20.1 & 21.6 & 25.0 & 21.1 & 22.4 & 1.71 & 0293 & 0.097 \\
\hline $\mathrm{g} / \mathrm{kg} \mathrm{BW}^{0.75}$ & 1.13 & 1.22 & 1.40 & 1.18 & 1.26 & 0.10 & 0.278 & 0.083 \\
\hline N retained & & & & & & & & \\
\hline $\mathrm{g} / \mathrm{d}$ & 8.31 & 11.0 & 14.9 & 11.7 & 12.7 & 1.44 & 0.021 & $0.028^{\mathrm{e}}$ \\
\hline $\mathrm{g} / \mathrm{kg} \mathrm{BW}^{0.75}$ & 0.47 & 0.62 & 0.84 & 0.65 & 0.72 & 0.09 & 0.012 & $0.019^{f}$ \\
\hline $\mathrm{g} / \mathrm{kg} \mathrm{N}$ intake & 292 & 387 & 473 & 428 & 457 & 38.2 & 0.008 & 0.081 \\
\hline $\mathrm{g} / \mathrm{kg} \mathrm{N}$ absorbed & 374 & 502 & 597 & 544 & 567 & 45.4 & 0.008 & $0.044^{g}$ \\
\hline $\mathrm{g}$ N/kg DOMI & 37.7 & 36.0 & 32.2 & 32.1 & 30.8 & 0.89 & 0.000 & 0.183 \\
\hline Serum urea $(\mathrm{mg} / \mathrm{dL})$ & 54.1 & 53.8 & 47.1 & 43.4 & 43.8 & 3.58 & 0.003 & 0.663 \\
\hline Urine urea $(\mathrm{mg} / \mathrm{dL})^{\prime}$ & 873 & 744 & 1081 & 1036 & 858 & 103 & 0.438 & 0.237 \\
\hline Urea $N(g / d)$ & 6.05 & 5.85 & 7.33 & 7.01 & 6.37 & 0.83 & 0.440 & 0.325 \\
\hline$\%$ of urine $\mathrm{N}$ & 51.1 & 53.8 & 71.5 & 74.7 & 64.9 & 5.48 & 0.005 & $0.038^{\mathrm{h}}$ \\
\hline Plasma ammonia (mg/L) & 6.30 & 6.35 & 5.95 & 4.88 & 5.04 & 0.48 & 0.004 & 0.745 \\
\hline Urine ammonia $(\mathrm{mg} / \mathrm{L})$ & 185 & 89 & 139 & 121 & 93 & 29.1 & 0.031 & 0.373 \\
\hline Ammonia N (g/d) & 0.22 & 0.12 & 0.14 & 0.13 & 0.11 & 0.04 & 0.034 & 0.187 \\
\hline$\%$ of urine $\mathrm{N}$ & 1.85 & 1.16 & 1.36 & 1.35 & 1.14 & 0.34 & 0.167 & 0.458 \\
\hline Glucose (mg/dL) & 50.1 & 54.9 & 55.7 & 59.7 & 56.1 & 3.97 & 0.007 & 0.053 \\
\hline
\end{tabular}

N: nitrogen; BW: body weight; DOMI: digestible organic matter intake; SEM: standard error of the mean; L: linear Q: quadratic. Linear and quadratic effects are significant at $p<0.05 .{ }^{\text {a }} \mathrm{N}$ intake $(\mathrm{g} / \mathrm{d})=-0.00003(\mathrm{SC}+\mathrm{UAS})^{2}+$ $0.0218(\mathrm{SC}+\mathrm{UAS})+26.086 .{ }^{\mathrm{b}} \mathrm{N}$ intake $\left(\mathrm{g} / \mathrm{kg} \mathrm{BW}^{0.75}\right)=-0.000002(\mathrm{SC}+\mathrm{UAS})^{2}+0.0012(\mathrm{SC}+\mathrm{UAS})+1.4691$ ${ }^{\mathrm{c}} \mathrm{N}$ faecal $=-0.000009(\mathrm{SC}+\mathrm{UAS})^{2}+0.0044(\mathrm{SC}+\mathrm{UAS})+5.9134 .{ }^{\mathrm{d}} \mathrm{N}$ urinary $=0.0009(\mathrm{SC}+\mathrm{UAS})^{2}-0.7076(\mathrm{SC}+\mathrm{UAS})+$ 471.31. ${ }^{\mathrm{e}} \mathrm{N}$ retained $(\mathrm{g} / \mathrm{d})=-0.00003(\mathrm{SC}+\mathrm{UAS})^{2}+0.0263(\mathrm{SC}+\mathrm{UAS})+8.3289 .{ }^{\mathrm{f}} \mathrm{N}$ retained $\left(\mathrm{g} / \mathrm{kg} \mathrm{BW}^{0.75}\right)=$ $-0.000002(\mathrm{SC}+\mathrm{UAS})^{2}+0.0014(\mathrm{SC}+\mathrm{UAS})+0.4726 . \mathrm{g}^{\mathrm{N}}$ retained $(\mathrm{g} / \mathrm{kg} \mathrm{N}$ absorbed $)=-0.0011(\mathrm{SC}+\mathrm{UAS})^{2}+$ $0.9682(\mathrm{SC}+\mathrm{UAS})+380.01 .{ }^{\mathrm{h}}$ Urea N $(\%)=-0.0001(\mathrm{SC}+\mathrm{UAS})^{2}+0.1076(\mathrm{SC}+\mathrm{UAS})+47.857$.

Table 6. Urinary volume, purine derivatives excretion and absorption, and microbial nitrogen and protein supply.

\begin{tabular}{|c|c|c|c|c|c|c|c|c|}
\hline \multirow{2}{*}{ Variable } & \multicolumn{5}{|c|}{ Inclusion of SC+UAS (g/kg DM) } & \multirow{2}{*}{ SEM } & \multicolumn{2}{|c|}{$p$-Value } \\
\hline & 0 & 150 & 300 & 450 & 600 & & $\mathbf{L}$ & $\mathbf{Q}$ \\
\hline Urinary volume $(\mathrm{L} / \mathrm{d})$ & 1.52 & 1.79 & 1.51 & 1.46 & 1.61 & 0.20 & 0.751 & 0.987 \\
\hline Allantoin $(\mathrm{mmol} / \mathrm{L})$ & 3.86 & 4.11 & 6.49 & 5.18 & 5.03 & 0.77 & 0.148 & 0.111 \\
\hline Allantoin $(\mathrm{mmol} / \mathrm{d})$ & 5.45 & 6.49 & 8.46 & 7.03 & 7.51 & 0.57 & 0.006 & $0.019^{a}$ \\
\hline Uric acid (mmol/L) & 0.50 & 0.60 & 0.97 & 0.89 & 0.93 & 0.10 & 0.002 & 0.132 \\
\hline Uric acid $(\mathrm{mmol} / \mathrm{d})$ & 0.73 & 0.95 & 1.35 & 1.16 & 1.40 & 0.11 & 0.000 & 0.116 \\
\hline PD excreted (mmol/d) & 6.18 & 7.43 & 9.81 & 8.19 & 8.91 & 0.60 & 0.001 & $0.011^{b}$ \\
\hline PD absorbed (mmol/d) & 6.71 & 8.43 & 11.5 & 9.44 & 10.3 & 0.79 & 0.001 & $0.009^{\mathrm{c}}$ \\
\hline $\operatorname{MNS}(\mathrm{g} / \mathrm{d})$ & 4.87 & 6.12 & 8.35 & 6.86 & 7.49 & 0.58 & 0.001 & $0.009^{d}$ \\
\hline $\operatorname{MPS}(\mathrm{g} / \mathrm{d})$ & 30.5 & 38.3 & 52.2 & 42.9 & 46.9 & 3.60 & 0.001 & $0.009 \mathrm{e}$ \\
\hline g MPS/kg DÓMI & 44.4 & 49.8 & 53.2 & 51.2 & 51.6 & 3.57 & 0.146 & 0.227 \\
\hline g MPS/kg DOMR & 68.3 & 76.6 & 81.8 & 78.7 & 79.4 & 5.49 & 0.146 & 0.225 \\
\hline
\end{tabular}

PD: purine derivatives; MNS: microbial nitrogen supply; MPS: microbial protein supply; DOMI: digestible organic matter intake; DOMR: digestible organic matter apparently digested in the rumen; SEM: standard error of the mean; L: linear; Q: quadratic. Linear and quadratic effects are significant at $p<0.05$. a Allantoin $(\mathrm{mmol} / \mathrm{d})=-0.00001(\mathrm{SC}+\mathrm{UAS})^{2}+0.0117(\mathrm{SC}+\mathrm{UAS})+5.4103 .{ }^{\mathrm{b}} \mathrm{PD}$ excreted $(\mathrm{mmol} / \mathrm{d})=-0.00002(\mathrm{SC}+\mathrm{UAS})^{2}+$ $0.0138(\mathrm{SC}+\mathrm{UAS})+6.1371 .{ }^{\mathrm{c}} \mathrm{PD}$ absorbed $(\mathrm{mmol} / \mathrm{d})=-0.00002(\mathrm{SC}+\mathrm{UAS})^{2}+0.0185(\mathrm{SC}+\mathrm{UAS})+6.6594$. $\mathrm{d}$ MNS $(\mathrm{g} / \mathrm{d})=-0.00002(\mathrm{SC}+\mathrm{UAS})^{2}+0.0134(\mathrm{SC}+\mathrm{UAS})+4.8334 . \quad$ e $\mathrm{MPS}(\mathrm{g} / \mathrm{d})=-0.0001(\mathrm{SC}+\mathrm{UAS})^{2}+$ $0.0836(\mathrm{SC}+\mathrm{UAS})+30.28$. 


\section{Discussion}

\subsection{DM, DOM, and iNDF Intake}

Dry matter intake (Table 3) increased quadratically from level 0 to $355.43 \mathrm{~g} \mathrm{SC}+\mathrm{UAS} / \mathrm{kg}$ $\mathrm{DM}$, probably due to the inclusion of SC, which has a highly effective ruminal DM degradability $(711 \mathrm{~g} / \mathrm{kg} \mathrm{DM}$ ) [8] as a result of its low NDF and lignin concentrations (148 and $10 \mathrm{~g} / \mathrm{kg}$ DM, respectively), and its high NFC concentration (712 g/kg DM; Table 1). In addition, the SC+UAS inclusion resulted in decreased iNDFI to levels below $150 \mathrm{~g} / \mathrm{kg} \mathrm{DM}$, a value above which DM intake can be limited [31].

Reduction in DM and DOM intakes (Table 3) were possibly due to metabolic regulation as a consequence of the increased propionate concentrations observed in this experiment (Table 4 and Figure 2). Farningham and Whyte [32] reported that propionate flow on the portal system has an important role in regulating intake, which is independent of changes regarding plasma insulin level. Oba and Allen [33] observed that increasing propionate concentrations through ruminal infusions decreased DM intake, metabolizable energy intake, meal size, and meal frequency. Propionate uptake by the liver can be used for gluconeogenesis, utilization of ATP, or oxidation in the tricarboxylic acid cycle through acetyl CoA. Propionate uptake during meals stimulates oxidation of acetyl $\mathrm{CoA}$ to $\mathrm{CO}_{2}$, rapidly generating ATP and stimulating satiety [34].

\subsection{Ruminal Fermentation}

Quadratic decrease in $\mathrm{pH}$ with collection time (Table 4) was caused by dietary carbohydrate fermentation [35], which generated the same quadratic response in total VFA concentration (Table 4). Subsequently, $\mathrm{pH}$ increased gradually as a consequence of rumen acids being extracted either via liquid phase passage or by absorption through the rumen wall. The linear reduction in rumen $\mathrm{pH}$ with increasing SC+UAS inclusion can be an effect of the fermentation of the high NFC levels in the SC diets (Table 2), resulting in greater total VFA production. Moreover, SC inclusion diminished rumination [7] due to low NDF concentration, which reduces saliva secretion and, consequently, rumen buffering capacity [36]. Ruminal pH did not reach values lower than 6.0 with SC+UAS inclusion. Therefore, cellulolysis $[37,38]$ and NDF digestibility could not be affected, as reported by Siqueira et al. [9].

The greatest RAN concentration was seen at $600 \mathrm{~g} \mathrm{SC}+\mathrm{UAS} / \mathrm{kg}$ DM two hours after feeding, despite showing the lowest RAN concentration at zero hours (Figure 1), possibly due to the greater UAS proportion and its high solubility in the rumen. The greater reduction at four hours with 300-600 $\mathrm{g} \mathrm{SC}+\mathrm{UAS} / \mathrm{kg}$ DM was possibly due to greater ruminal synchrony of $\mathrm{N}$ to readily fermentable carbohydrate [39], which could be a consequence of a greater NFC content of SC, plus the use of two rapidly rumen-degradable non-protein Nsources, such as UAS. The use of that source in diets with rapidly rumen-fermentable energy promotes greater RAN efficiency by rumen microbes in microbial protein synthesis $[40,41]$.

Ruminal $\mathrm{pH}$ reduction resulting from $\mathrm{SC}+\mathrm{UAS}$ inclusion could influence the lower RAN concentration from $300 \mathrm{~g}$ SC+UAS $/ \mathrm{kg}$ DM level after the peak at two hours following the first feeding (Figure 1). The ruminal wall permeability toward ammonia absorption as $\mathrm{NH}_{3}$ is 175 times greater than as $\mathrm{NH}_{4}{ }^{+}$when the ruminal $\mathrm{pH}$ is below 6.4. However, $\mathrm{NH}_{3}$ concentration is lower than $\mathrm{NH}_{4}{ }^{+}$; therefore, $70 \%$ of the ammonia will be absorbed through the rumen wall as $\mathrm{NH}_{4}{ }^{+}$by potassium-facilitated transport [42]. Thus, $\mathrm{NH}_{4}{ }^{+}$ions cannot rapidly be removed through the rumen wall into the blood [43], meaning that they are stored for longer in the rumen. Therefore, $\mathrm{NH}_{4}{ }^{+}$ions can be captured by microbes for protein synthesis [44], consequently decreasing RAN.

Inclusion levels of SC at all collection times promoted RAN concentrations greater than $50 \mathrm{mg} / \mathrm{L}$ (Figure 1). According to Satter and Slyter [45], this value is enough to support an adequate rumen bacterial growth rate. Two hours after feeding, all inclusion levels reached RAN concentrations greater than $235 \mathrm{mg} / \mathrm{L}$, a value suggested by Mehrez et al. [46] to be the point of maximal dietary OM degradation. Detmann et al. [47] suggested that for 
diets based on medium- to-high-quality forages, supplementation should increase RAN concentrations above $160 \mathrm{mg} / \mathrm{L}$, a value reached from $0-4 \mathrm{~h}$ at $0 \mathrm{~g} \mathrm{SC}+\mathrm{UAS} / \mathrm{kg} \mathrm{DM}$.

Acetate concentration usually increases with structural carbohydrate fermentation in the diet [48]. However, in the present experiment there was a linear increase in acetate concentration with increasing SC+UAS inclusion (Table 4) as NDF decreased (Table 2), differing by $18 \%$ between the 0 and $600 \mathrm{~g} \mathrm{SC}+\mathrm{UAS} / \mathrm{kg}$ DM treatments. The increase in the acetate concentration with SC inclusion could be due to its high content of fructans and $\beta$-glucans [49], both of which are constituents of the neutral detergent-soluble fiber [50]. Fructans are fermented by some rumen bacteria that produce acetate [51].

The increase of propionate concentration with increasing SC+UAS inclusion, with the highest values observed after feeding with $300 \mathrm{~g} \mathrm{SC}+\mathrm{UAS} / \mathrm{kg}$ DM (Figure 2), could be a consequence of NFC fermentation [48]. Pectin is a constituent of NFC [50] and is found in SC [49]. It is rich in rhamnose [52], the anaerobic fermentation of which generates ethanol, acetone, and 1,2-propanediol [53]. The latter is fermented by rumen bacteria that produce propionate [54]. Greater propionic acid production with SC+UAS inclusion promotes a linear decrease in the ratio of acetate to propionate (Table 4), which is also related to rumen $\mathrm{pH}$ decrease [35].

\subsection{Nitrogen Balance, Nitrogen Compounds, and Blood Glucose}

The quadratic increase in N-intake $\left(\mathrm{g} / \mathrm{d}\right.$ and $\left.\mathrm{g} / \mathrm{kg} \mathrm{BW}^{0.75}\right)$ and its excretion through feces (Table 5) was possibly a consequence of the same response observed for DM intake (Table 3). Greater DM intake implies higher intake of concentrate consisting mainly of corn (Table 2). This ingredient increases the amount of microbial-originated $\mathrm{N}$ via feces, due to its greater fermentative activity in the large intestine [55].

Using diets higher in rumen-degradable protein increases the $\mathrm{N}$-excretion via urine [56]. In this experiment, the inclusion of UAS to adjust the crude protein concentration of diets increased the amount of degradable $\mathrm{N}$ in the rumen, although urine $\mathrm{N}$-excretion decreased (Table 5). The greatest $\mathrm{N}$-intake was observed at $363 \mathrm{~g} \mathrm{SC}+\mathrm{UAS} / \mathrm{kg} \mathrm{DM}$, although its excretion in feces decreased from $244 \mathrm{~g} \mathrm{SC}+\mathrm{UAS} / \mathrm{kg}$ DM, in addition to the decreased urinary $\mathrm{N}$-excretion. This response allows the inference of a greater $\mathrm{N}$-use by animals at that level of SC+UAS inclusion in the diet. A greater use of energy and a protein diet for microbial protein synthesis generates lower N-loss [57], and the greater utilization was up to $438 \mathrm{~g} \mathrm{SC}+\mathrm{UAS} / \mathrm{kg}$ DM when the greatest $\mathrm{N}$-retention was reached.

Inclusion levels of 0 and $150 \mathrm{~g}$ SC+UAS/ $\mathrm{kg}$ DM showed consumptions in excess of $33.6 \mathrm{~g} \mathrm{~N} / \mathrm{kg}$ DOM; therefore, losses of protein or incomplete net transfer could occur [58], which explains the lower N-retention at these levels of inclusion. At $300 \mathrm{~g} \mathrm{SC}+\mathrm{UAS} / \mathrm{kg}$ $\mathrm{DM}$, consumption was higher than $16 \mathrm{~g} \mathrm{~N} / \mathrm{kg}$ DOM; hence, there was no N-limitation for microbial protein synthesis [59]. However, retained $\mathrm{N}$ decreased from inclusion level of $438 \mathrm{~g} \mathrm{SC}+\mathrm{UAS} / \mathrm{kg}$ DM; therefore, other factors generated the decrease in the use of $\mathrm{N}$ from this level of inclusion.

The dietary N-usage was also reflected on both serum urea and plasma ammonia (Table 5), with a linear decrease in their concentrations with increasing SC+UAS inclusion. Blood urea values were within the normal range for sheep $(24-60 \mathrm{mg} / \mathrm{dL})$ [60], and plasma ammonia concentrations were lower than the limit for intoxication $(10-40 \mathrm{mg} / \mathrm{L})$ [61].

Urine urea concentration and its daily excretion (Table 5) were not influenced by $\mathrm{SC}+\mathrm{UAS}$ inclusion, although blood concentration levels differed. The amount of urea excreted in the urine is determined by the amount of urea filtered at the kidney glomeruli [62] However, N-intake between 26.0 and $31.6 \mathrm{~g} / \mathrm{d}$ (Table 5) could generate the same rate of clearance of urea from the plasma by the kidneys, as observed by Cocimano and Leng [63]; despite the greater concentration of urea in blood and similar amount in the urine (Table 6), a similar urea excretion was generated.

Szanyiová et al. [64] reported when sheep were fed high- or low-N diets (28.71 vs. $9.32 \mathrm{~g} / \mathrm{d}$ ), the $\mathrm{N}$ excreted through urine as urea as a proportion of total urinary $\mathrm{N}$ was not affected (74 vs. $69 \%$ ). In the present experiment, N-excretion in the urine as urea 
as a proportion of the total urinary $\mathrm{N}$ showed a quadratic response, despite daily urea excretion in grams was similar between treatments; the difference is possibly due to the total N-excretion through urine being reduced.

Ammonia concentration and daily N-excretion as ammonia through urine (Table 5) showed the same response as serum urea and plasma ammonia. Free ammonia in extrahepatic tissues binds with glutamate to produce glutamine, which transports ammonia via blood to the liver to produce urea, or even to the kidneys, where glutamine degradation generates ammonia release in the urine [65]. Therefore, there was possibly a decrease in ammonia production by extrahepatic tissues with increasing SC+UAS inclusion.

Glucose concentrations were within the reference levels of $43-76 \mathrm{mg} / \mathrm{dL}$, as suggested by Contreras et al. [60]. The linear increase in glucose concentration with increasing SC+UAS inclusion (Table 5) may be a consequence of the same response observed in rumen propionic acid concentration, since this acid is a substrate for gluconeogenesis and the main glucose source for ruminants $[48,66]$. Moreover, the dietary glucose absorption is greatly reduced in ruminants [67].

\subsection{Urinary Volume, $P D$, and MPS}

Vieira et al. [68] reported that the diuretic effect of SC is promoted by its high $\mathrm{K}$ and low $\mathrm{Na}$ contents, despite this inclusion having no influence on urinary volume (Table 6). This response was different from those reported by other authors when SC was included in the diet $[69,70]$.

The quadratic increase in PD excretion with increasing SC+UAS inclusion (Table 6) could be a consequence of the same effect, as observed for DM intake, given the correlation between them when DM intake is adjusted for BW [16,71]. For example, greater PD excretion was observed at $345 \mathrm{~g}$ SC+UAS/ $\mathrm{kg}$ DM, which matched the greater DM intake (g/kg BW) at $343 \mathrm{~g} \mathrm{SC+UAS/kg} \mathrm{DM.}$

According to Van Soest [36], greater DM intake reduces the energetic cost of maintaining rumen microbes because the residence time in the rumen is also decreased. In addition, due to the greater DM intake, rumen particle flow is increased and the number of bacteria adhering to feed that escapes from rumen to abomasum and duodenum is increased, so the flow of microbial $\mathrm{N}$ is greater, promoting higher microbial purine absorption [15]. At $335 \mathrm{~g}$ $\mathrm{SC}+\mathrm{UAS} / \mathrm{kg} \mathrm{DM}$, the maximum MNS was produced, at which the RAN concentration was estimated at $147 \mathrm{mg} / \mathrm{L}(\mathrm{RAN}=164.96-0.0537 \times \mathrm{SC}+\mathrm{UAS})$, close to that observed by Detmann et al. [72], who reported maximum MNS at a RAN concentration of $145 \mathrm{mg} / \mathrm{L}$.

In the present experiment, a quadratic increase in MPS was observed. In contrast, Cardoso et al. [5] and Barros et al. [73] found a linear increase in MPS when SC was included in lamb (450 g/ kg DM) and heifer (500 g/ kg DM) diets, respectively. This different response may be due to the roughage/concentrate ratio being 50:50 in the experiments mentioned above, and 70:30 in our research.

The gradual increase of MPS until the inclusion reached $418 \mathrm{~g} \mathrm{SC}+\mathrm{UAS} / \mathrm{kg}$ DM could be due to the use of the energy contained in the NFC of the SC, mostly as a result of rapid ruminal degradation [49], and the energy provided by slow degradation of the structural carbohydrates of Tifton hay (cellulose and hemicellulose). These two different rates of carbohydrate degradation are able to maintain a constant supply of ATP for microbial growth [74]. Additionally, the feed contained non-protein N-sources for rapid ruminal degradation (a UAS mix) that maximize microbial growth, and bacteria that ferment NFC grow faster than those that ferment structural carbohydrates $[75,76]$.

In addition to the DM intake reduction from the level $356 \mathrm{~g} \mathrm{DM} / \mathrm{kg}$, which could negatively influence microbial protein synthesis, the decrease in rumen $\mathrm{pH}$ (close to 6.0) would contribute to lower MPS, even when a reduction in RAN with SC+UAS inclusion is associated with greater microbial protein utilization. Ruminal $\mathrm{pH}$ values of 6.0 generate lower ATP synthesis because bacteria use it for non-growth functions, such as intracellular $\mathrm{pH}$ maintenance [77]. 
With decreases in RAN, blood urea and ammonia concentrations (as indicators of dietary N-utilization), and consumption over $16 \mathrm{~g} \mathrm{~N} / \mathrm{kg}$ DOM, the lower MPS as from $418 \mathrm{~g}$ SC+UAS $/ \mathrm{kg}$ DM would be directly associated with the rumen environment. The great amounts of fermentable carbohydrates in diets with high SC+UAS levels increase VFAs and consequently decrease rumen $\mathrm{pH}$, which increases bacterial energy demand. This lower production of MPS could explain the decrease in retained $\mathrm{N}(\mathrm{g} / \mathrm{d})$.

Despite SC+UAS inclusion having an influence on MNS and MPS, the efficiency of MPS was not influenced by inclusion (Table 6). The values of the efficiency of MPS per $\mathrm{kg}$ of DOM intake and $\mathrm{kg}$ of DOMR were lower than those recommended by Balch [78] (130 g MPS/kg DOM, or $200 \mathrm{~g}$ MPS/kg DOMR). Pereira et al. [79] also observed low MPS efficiency ( $47.4 \mathrm{~g} / \mathrm{kg}$ total digestible nutrient intake) in sheep fed ad libitum under tropical conditions, a value lower than that recommended by NRC [14] (130 g/kg).

\section{Conclusions}

In diets for wethers with a roughage/concentrate ratio of 70:30, roughage consisting of a SC+UAS/hay (Tifton-85) ratio of 41:29 is recommended to maximize DOM intake, $\mathrm{N}$-retention, and MPS. This could lead to improvements in the productive performance of the animals in semi-arid regions.

Author Contributions: Conceptualization, M.A.F., A.S.C.V. and F.F.R.C.; resources, M.A.F., A.S.C.V. and F.F.R.C.; funding acquisition, M.A.F.; supervision, M.A.F., J.C.C.C. and M.G.d.C.; project administration, M.A.F.; investigation, R.E.M.-L., A.M.H.-A., M.C.B.S. and M.G.d.C.; methodology, R.E.M.-L., A.M.H.-A., M.C.B.S., A.S.C.V., F.F.R.C. and M.A.F.; formal analysis, R.E.M.-L. and A.M.H.A.; writing-original draft, R.E.M.-L.; writing—review and editing, R.E.M.-L., M.A.F., J.C.C.C. and C.C.F.M. All authors have read and agreed to the published version of the manuscript.

Funding: This research was funded by CAPES.

Institutional Review Board Statement: Ethics approval-The Ethics Committee of the Federal Rural University of Pernambuco approved the study (License No. 069/2016).

Data Availability Statement: Data are available upon request from the corresponding authors.

Conflicts of Interest: The authors declare no conflict of interest.

\section{References}

1. Chedid, M.; Jaber, L.S.; Giger-Reverdin, S.; Duvaux-Ponter, C.; Hamadeh, S.K. Review: Water stress in sheep raised under arid conditions. Can. J. Anim. Sci. 2014, 94, 243-257. [CrossRef]

2. Safriel, U.; Adeel, Z.; Niemeijer, D.; Puigdefabregas, J.; White, R.; Lal, R.; Winslow, M.; Ziedler, J.; Prince, S.; Archer, E.; et al. Dryland Systems. In Ecosystems and Human Well-being: Current State and Trends; Hassan, R., Scholes, R., Ash, N., Eds.; ISLAND PRESS: Washington, DC, USA, 2005; Volume I, pp. 623-662. ISBN 0027-8424.

3. Huang, J.; Ji, M.; Xie, Y.; Wang, S.; He, Y.; Ran, J. Global semi-arid climate change over last 60 years. Clim. Dyn. 2016, 46, 1131-1150. [CrossRef]

4. Júnior, J.G.B.G.; Silva, J.B.A.; Morais, J.H.G.; Lima, R.N. Palma forrageira na alimentação de ruminantes: Cultivo e utilização. Acta Vet. Bras. 2014, 8, 78-85. [CrossRef]

5. Cardoso, D.B.; Carvalho, F.F.R.; Medeiros, G.R.; Guim, A.; Cabral, A.M.D.; Véras, R.M.L.; Santos, K.C.; Dantas, L.C.N.; Nascimento, A.G.O. Levels of inclusion of spineless cactus (Nopalea cochenillifera Salm Dyck) in the diet of lambs. Anim. Feed Sci. Technol. 2019, 247, 23-31. [CrossRef]

6. Inácio, J.G.; Conceicąõ, M.G.; Santos, D.C.; Oliveira, J.C.V.; Chagas, J.C.C.; Oliveira Moraes, G.S.; Silva, E.T.S.; Ferreira, M.A Nutritional and performance viability of cactus Opuntia-based diets with different concentrate levels for Girolando lactating dairy cows. Asian-Australas. J. Anim. Sci. 2020, 33, 35-43. [CrossRef]

7. Siqueira, M.C.B.; Ferreira, M.A.; Monnerat, J.P.I.S.; Silva, J.L.; Costa, C.T.F.; Conceição, M.G.; Soares, A.A.; Andrade, I.B.; Chagas, J.C.C. Nutritional performance and metabolic characteristics of cattle fed spineless cactus. J. Agric. Sci. Technol. 2018, $20,13-22$.

8. Batista, A.M.V.; Ribeironeto, A.C.; Lucena, R.B.; Santos, D.C.; Dubeux, J.B.; Mustafa, A.F. Chemical composition and ruminal degradability of spineless cactus grown in Northeastern Brazil. Rangel. Ecol. Manag. 2009, 62, 297-301. [CrossRef]

9. Siqueira, M.C.B.; Ferreira, M.A.; Monnerat, J.P.I.S.; Silva, J.L.; Costa, C.T.F.; Conceição, M.G.; Andrade, R.P.X.; Barros, L.J.A.; Melo, T.T.B. Optimizing the use of spineless cactus in the diets of cattle: Total and partial digestibility, fiber dynamics and ruminal parameters. Anim. Feed Sci. Technol. 2017, 226, 56-64. [CrossRef] 
10. Taffarel, L.E.; Mesquita, E.E.; Castagnara, D.D.; Oliveira, P.S.R.; Oliveira, N.T.E.; Galbeiro, S.; Costa, P.B. Produção de matéria seca e valor nutritivo do feno do tifton 85 adubado com nitrogênio e colhido com 35 dias. Rev. Bras. Saúde Produção Anim. 2014, 15, 544-560. [CrossRef]

11. Hill, G.M.; Gates, R.N.; Burton, G.W. Forage quality and grazing steer performance from Tifton 85 and Tifton 78 bermudagrass pastures. J. Anim. Sci. 1993, 71, 3219-3225. [CrossRef]

12. Peel, M.C.; Finlayson, B.L.; McMahon, T.A. Updated world map of the Köppen-Geiger climate classificatio. Hydrol. Earth Syst. Sci. 2007, 11, 1633-1644. [CrossRef]

13. Machado, M.G.; Detmann, E.; Mantovani, H.C.; Valadares Filho, S.C.; Bento, C.B.P.; Marcondes, M.I.; Assunção, A.S. Evaluation of the length of adaptation period for changeover and crossover nutritional experiments with cattle fed tropical forage-based diets. Anim. Feed Sci. Technol. 2016, 222, 132-148. [CrossRef]

14. National Research Council (NRC). Nutrient Requirements of Small Ruminants. Sheep, Goats, Cervids and New World Camelids; The National Academies, Ed.; The National Academies Press: Washington, DC, USA, 2007.

15. Chen, X.B.; Hovell, F.D.D.; Ørskov, E.R.; Brown, D.S. Excretion of purine derivatives by ruminants: Effect of exogenous nucleic acid supply on purine derivative excretion by sheep. Br. J. Nutr. 1990, 63, 131-142. [CrossRef]

16. Chen, X.B.; Chen, Y.K.; Franklin, M.F.; Ørskov, E.R.; Shand, W.J. The effect of feed intake and body weight on purine derivative excretion and microbial protein supply in sheep. J. Anim. Sci. 1992, 70, 1534-1542. [CrossRef]

17. Chen, X.B.; Gomes, M.J. Estimation of Microbial Protein Supply to Sheep and Cattle Based on Urinary Excretion of Purine Derivatives-An Overview of the Technical Details; Rowett Research Institute: Aberdeen, UK, 1992.

18. AOAC. Animal feed. In Association of Official Analytical Chemists (AOAC); Helrich, K., Ed.; Association of Official Analytical Chemists, Inc.: Arlington, VA, USA, 1990; Volume I, pp. 69-90.

19. Krizsan, S.J.; Huhtanen, P. Effect of diet composition and incubation time on feed indigestible neutral detergent fiber concentration in dairy cows. J. Dairy Sci. 2013, 96, 1715-1726. [CrossRef]

20. Mertens, D.R. Gravimetric determination of amylase-treated neutral detergent fiber in feeds with refluxing in beakers or crucibles: Collaborative study. J. AOAC Int. 2002, 85, 1217-1240.

21. Licitra, G.; Hernandez, T.M.; Van Soest, P.J. Standardization of procedures for nitrogen fractionation of ruminant feeds. Anim. Feed Sci. Technol. 1996, 57, 347-358. [CrossRef]

22. Van Soest, P.J. Collaborative study of acid-detergent fiber and lignin. J. AOAC 1973, 56, 781-784. [CrossRef]

23. Van Soest, P.J.; Wine, R.H. Determination of lignin and cellulose in acid-detergent fiber with permanganate. J. AOAC 1968, 51, 780-785. [CrossRef]

24. Erwin, E.S.; Marco, G.J.; Emery, E.M. Volatile fatty acid analyses of blood and rumen fluid by gas chromatography. J. Dairy Sci. 1961, 44, 1768-1771. [CrossRef]

25. Chaney, A.L.; Marbach, E.P. Modified reagents for determination of urea and ammonia. Clin. Chem. 1962, 8, 130-132. [CrossRef] [PubMed]

26. Leffler, H.H. Measurement of ammonia in plasma. Am. J. Clin. Pathol. 1967, 48, 233-236. [CrossRef]

27. Detmann, E.; Filho, S.C.V. On the estimation of non-fibrous carbohydrates in feeds and diets. Arq. Bras. Med. Veterinária Zootec. 2010, 62, 980-984. [CrossRef]

28. Topps, J.H.; Elliott, R.C. Relationship between concentrations of ruminal nucleic acids and excretion of purine derivatives by sheep. Nature 1965, 205, 498-499. [CrossRef]

29. AFRC. Energy and Protein Requirements of Ruminants. An Advisory Manual Prepared by the AFRC Technical Committee on Responses to Nutrients; CAB International: Wallingford, UK, 1995; ISBN 0-85198-851-2.

30. Littell, R.C.; Henry, P.R.; Ammerman, C.B. Statistical analysis of repeated measures data using SAS procedures. J. Anim. Sci. 1998, 76, 1216-1231. [CrossRef] [PubMed]

31. Lippke, H. Regulation of voluntary intake of ryegrass and sorghum forages in cattle by indigestible neutral detergent fiber. $J$. Anim. Sci. 1986, 63, 1459-1468. [CrossRef]

32. Farningham, D.A.H.; Whyte, C.C. The role of propionate and acetate in the control of food intake in sheep. Br. J. Nutr. 1993, 70,37-46. [CrossRef] [PubMed]

33. Oba, M.; Allen, M.S. Intraruminal infusion of propionate alters feeding behavior and decreases energy intake of lactating dairy cows. J. Nutr. 2003, 133, 1094-1099. [CrossRef]

34. Allen, M.S.; Bradford, B.J.; Oba, M. Board-invited review: The hepatic oxidation theory of the control of feed intake and its application to ruminants. J. Anim. Sci. 2009, 87, 3317-3334. [CrossRef]

35. Dijkstra, J.; Ellis, J.L.; Kebreab, E.; Strathe, A.B.; López, S.; France, J.; Bannink, A. Ruminal pH regulation and nutritional consequences of low pH. Anim. Feed Sci. Technol. 2012, 172, 22-33. [CrossRef]

36. Van Soest, P.J. Nutritional Ecology of the Ruminant, 2nd ed.; Cornell University Press: Ithaca, NY, USA, 1994.

37. Mould, F.L.; Ørskov, E.R. Manipulation of rumen fluid pH and its influence on cellulolysis in sacco, dry matter degradation and the rumen microflora of sheep offered either hay or concentrate. Anim. Feed Sci. Technol. 1983, 10, 1-14. [CrossRef]

38. Mouriño, F.; Akkarawongsa, R.; Weimer, P.J. Initial $\mathrm{pH}$ as a determinant of cellulose digestion rate by mixed ruminai microorganisms in vitro. J. Dairy Sci. 2001, 84, 848-859. [CrossRef] 
39. Seo, J.K.; Yang, J.; Kim, H.J.; Upadhaya, S.D.; Cho, W.M.; Ha, J.K. Effects of synchronization of carbohydrate and protein supply on ruminal fermentation, nitrogen metabolism and microbial protein synthesis in holstein steers. Asian-Australas. J. Anim. Sci. 2010, 23, 1455-1461. [CrossRef]

40. Roffler, R.E.; Satter, L.D. Relationship between ruminal ammonia and nonprotein nitrogen utilization by ruminants. I. Development of a model for predicting nonprotein nitrogen utilization by cattle. J. Dairy Sci. 1975, 58, 1880-1888. [CrossRef]

41. Satter, L.D.; Roffler, R.E. Nitrogen requirement and utilization in dairy cattle. J. Dairy Sci. 1975, 58, 1219-1237. [CrossRef]

42. Abdoun, K.; Stumpff, F.; Martens, H. Ammonia and urea transport across the rumen epithelium: A review. Anim. Health Res. Rev. 2006, 7, 43-59. [CrossRef]

43. Haliburton, J.C.; Morgan, S.E. Nonprotein nitrogen-induced ammonia toxicosis and ammoniated feed toxicity syndrome. Vet. Clin. N. Am. Food Anim. Pract. 1989, 5, 237-249. [CrossRef]

44. Cabrita, A.R.J.; Dewhurst, R.J.; Abreu, J.M.F.; Fonseca, A.J.M. Evaluation of the effects of synchronising the availability of N and energy on rumen function and production responses of dairy cows-A review. Anim. Res. INRA 2006, 55, 1-24. [CrossRef]

45. Satter, L.D.; Slyter, L.L. Effect of ammonia concentration on rumen microbial protein production in vitro. Br. J. Nutr. 1974, 32, 199-208. [CrossRef]

46. Mehrez, A.Z.; Ørskov, E.R.; McDonald, I. Rates of rumen fermentation in relation to ammonia concentration. Br. J. Nutr. 1977, 38, 437-443. [CrossRef]

47. Detmann, E.; Paulino, M.F.; Filho, S.C.V.; Huhtanen, P. Nutritional aspects applied to grazing cattle in the tropics: A review based on Brazilian results. Semin. Agrárias 2014, 35, 2829-2854. [CrossRef]

48. Dijkstra, J. Production and absorption of the volatile acids in the rumen. Livest. Prod. Sci. 1994, 39, 61-69. [CrossRef]

49. Batista, A.M.; Mustafa, A.F.; McAllister, T.; Wang, Y.; Soita, H.; McKinnon, J.J. Effects of variety on chemical composition, in situ nutrient disappearance and in vitro gas production of spineless cacti. J. Sci. Food Agric. 2003, 83, 440-445. [CrossRef]

50. Hall, M.B. Challenges with nonfiber carbohydrate methods. J. Anim. Sci. 2003, 81, 3226-3232. [CrossRef] [PubMed]

51. Piknova, M.; Guczynska, W.; Miltko, R.; Javorsky, P.; Kasperowicz, A.; Michalowski, T.; Pristas, P. Treponema zioleckii sp. nov., a novel fructan-utilizing species of rumen treponemes. FEMS Microbiol. Lett. 2008, 289, 166-172. [CrossRef] [PubMed]

52. Voragen, A.G.J.; Coenen, G.-J.; Verhoef, R.P.; Schols, H.A. Pectin, a versatile polysaccharide present in plant cell walls. Struct. Chem. 2009, 20, 263-275. [CrossRef]

53. Weimer, P.J. Fermentation of 6-deoxyhexoses by Bacillus macerans. Appl. Environ. Microbiol. 1984, 47, 263-267. [CrossRef] [PubMed]

54. Czerkawski, J.W.; Piatkova, M.; Breckenridge, G. Microbial metabolism of 1,2-propanediol studied by the Rumen Simulation Technique (Rusitec). J. Appl. Bacteriol. 1984, 56, 81-94. [CrossRef]

55. Kozloski, G.V. Bioquímica dos Ruminantes, 3rd ed.; Editoria UFSM: Santa Maria, Brazil, 2019.

56. Hristov, A.N.; Etter, R.P.; Ropp, J.K.; Grandeen, K.L. Effect of dietary crude protein level and degradability on ruminal fermentation and nitrogen utilization in lactating dairy cows. J. Anim. Sci. 2004, 82, 3219-3229. [CrossRef]

57. Reynolds, C.K.; Kristensen, N.B. Nitrogen recycling through the gut and the nitrogen economy of ruminants: An asynchronous symbiosis. J. Anim. Sci. 2008, 86, E293-E305. [CrossRef]

58. Poppi, D.P.; McLennan, S.R. Protein and energy utilization by ruminants at pasture. J. Anim. Sci. 1995, 73, 278-290. [CrossRef]

59. Hogan, J.P. Digestion and utilization of protein. In Nutritional Limits to Animal Production from Pastures, Proceedings of an International Symposium, St. Lucia, QLD, Australia, 24-28 August 1981; Hacker, J.B., Ed.; Commonwealth Agricultural Bureaux: Slough, UK, 1982; pp. 245-257.

60. Contreras, P.A.; Wittwer, F.; Böhmwald, H. Uso dos perfis metabólicos no monitoramento nutricional dos ovinos. In Perfil metabólico em Ruminantes: Seu uso em Nutrição e Doenças Nutricionais; González, F.H.D., Barcellos, J.O., Ospina, H., Ribeiro, L.A.O., Eds.; Gráfica da Universidade Federal do Rio Grande do Sul: Porto Alegre, Brasil, 2000; pp. 75-84.

61. Chalupa, W. Problems in feeding urea to ruminants. J. Anim. Sci. 1968, 27, 207-219. [CrossRef]

62. Maloiy, G.M.O.; Scott, D. Renal excretion of urea and electrolytes in sheep and red deer. J. Physiol. 1969, 205, 91-101. [CrossRef]

63. Cocimano, M.R.; Leng, R.A. Metabolism of urea in sheep. Br. J. Nutr. 1967, 21, 353-371. [CrossRef]

64. Szanyiová, M.; Leng, L.; Faix, Š. Partition of nitrogenous substances in the urine of sheep on different dietary protein intakes. Vet. Res. 1995, 26, 27-31.

65. Nelson, D.L.; Cox, M.M. Princípios de Bioquimica de Lehinger, 6th ed.; ARTMED EDITORA LTDA: Porto Alegre, Brazil, 2014; ISBN 9781429234146.

66. Huntington, G.B. Energy metabolism in the digestive tract and liver of cattle: Influence of physiological state and nutrition. Reprod. Nutr. Dev. 1990, 30, 35-47. [CrossRef]

67. Huntington, G.B.; Reynolds, C.K. Oxygen consumption and metabolite flux of bovine portal-drained viscera and liver. J. Nutr. 1987, 117, 1167-1173. [CrossRef]

68. Vieira, E.L.; Batista, Â.M.V.; Mustafa, A.F.; Araújo, R.F.S.; Soares, P.C.; Ortolane, E.L.; Mori, C.K. Effects of feeding high levels of cactus (Opuntia fícus-indica Mill) cladodes on urinary output and electrolyte excretion in goats. Livest. Sci. 2008, 114, 354-357. [CrossRef]

69. Neto, J.P.; Soares, P.C.; Batista, Â.M.V.; Andrade, S.F.J.; Andrade, R.P.X.; Lucena, R.B.; Guim, A. Balanço hídrico e excreção renal de metabólitos em ovinos alimentados com palma forrageira (Nopalea cochenillifera Salm Dyck). Pesqui. Veterinária Bras. 2016, 36, 322-328. [CrossRef] 
70. Rezende, F.M.; Véras, A.S.C.; Siqueira, M.C.B.; Conceição, M.G.; Lima, C.L.; Almeida, M.P.; Mora-Luna, R.E.; Neves, M.L.M.W.; Monteiro, C.C.F.; Ferreira, M.A. Nutritional effects of using cactus cladodes (Opuntia stricta Haw Haw) to replace sorghum silage in sheep diet. Trop. Anim. Health Prod. 2020, 52, 1875-1880. [CrossRef]

71. Santos, A.C.S.; Santos, S.A.; Carvalho, G.G.P.; Mariz, L.D.S.; Tosto, M.S.L.; Valadares Filho, S.C.; Azevedo, J.A.G. A comparative study on the excretion of urinary metabolites in goats and sheep to evaluate spot sampling applied to protein nutrition trials. $J$. Anim. Sci. 2018, 96, 3381-3397. [CrossRef] [PubMed]

72. Detmann, E.; Paulino, M.F.; Mantovani, H.C.; Filho, S.C.V.; Sampaio, C.B.; Souza, M.A.; Lazzarini, Í.; Detmann, K.S.C. Parameterization of ruminal fibre degradation in low-quality tropical forage using Michaelis-Menten kinetics. Livest. Sci. 2009, 126, 136-146. [CrossRef]

73. Barros, L.J.A.; Ferreira, M.A.; Oliveira, J.C.V.; Santos, D.C.; Chagas, J.C.C.; Alves, A.M.S.V.; da Silva, A.E.M.; Freitas, W.R. Replacement of Tifton hay by spineless cactus in Girolando post-weaned heifers' diets. Trop. Anim. Health Prod. 2018, 50, 149-154. [CrossRef] [PubMed]

74. Pathak, A.K. Various factors affecting microbial protein synthesis in the rumen. Vet. World 2008, 1, 186-189.

75. Russell, J.B.; O'Connor, J.D.; Fox, D.G.; Van Soest, P.J.; Sniffen, C.J. A net carbohydrate and protein system for evaluating cattle diets: I. Ruminal fermentation. J. Anim. Sci. 1992, 70, 3551-3561. [CrossRef] [PubMed]

76. Sniffen, C.J.; Robinson, P.H. Microbial growth and flow as influenced by dietary manipulations. J. Dairy Sci. 1987, 70, $425-441$. [CrossRef]

77. Strobel, H.J.; Russell, J.B. Effect of $\mathrm{pH}$ and energy spilling on bacterial protein synthesis by carbohydrate-limited cultures of mixed rumen bacteria. J. Dairy Sci. 1986, 69, 2941-2947. [CrossRef]

78. Balch, C.C. Report of the Protein Group of the Agricultural Research Council Working Party on the Nutrient Requirements of Ruminants; Commonwealth Agricultural Bureaux and Agricultural Research Council (Great Britain): Farnham Royal, UK, 1984.

79. Pereira, E.S.; Pereira, M.W.F.; Marcondes, M.I.; de Medeiros, A.N.; de Oliveira, R.L.; da Silva, L.P.; Mizubuti, I.Y.; Campos, A.C.N.; Heinzen, E.L.; Veras, A.S.C.; et al. Maintenance and growth requirements in male and female hair lambs. Small Rumin. Res. 2018, 159, 75-83. [CrossRef] 